\title{
Supply Chain Management Practices and Challenges for the SMEs in Kenya, a Case Study of the SMEs in the Tea Industry in Kenya
}

\author{
Kennedy O. Moenga \\ Department of Business Administration, Faculty of Business Studies, Chuka, Nairobi City, Kenya \\ Email address: \\ moengak@yahoo.com
}

\section{To cite this article:}

Kennedy O. Moenga. Supply Chain Management Practices and Challenges for the SMEs in Kenya, a Case Study of the SMEs in the Tea Industry in Keny. Science Journal of Business and Management. Vol. 4, No. 3, 2016, pp. 82-89. doi: 10.11648/j.sjbm.20160403.14

Received: May 3, 2016; Accepted: May 20, 2016; Published: June 1, 2016

\begin{abstract}
The main objective of the paper is to explore the nature of supply chain management practices and challenges that SMEs, which comprise of about $90 \%$ of businesses in the developing countries, face in Africa and more specifically in Kenya. The paper also identified important areas that need to be addressed in order to increase the SMEs long term survival and competitiveness in the business environment. A case study involving a supply chain network of the Small Scale tea Sector in Kenya was studied. Data was collected from forty eight respondents using semi-structured interviews, a structured questionnaire and examination of documents. The study found out that the SME sector appreciates good supply chain management practices, but has not put the same into practice. The sector has not established long term relationships with its suppliers. The sector was found to face several challenges which threaten its long term growth and survival, the most worrying challenge being the continued rising operating costs, adverse climatic changes and unpredictable working environment. This study is limited to the Kenyan small scale tea Industry. To improve generalization, the study could be replicated in other industry sectors of the economy and also in other developing countries. This paper provides a study that can help supply chain managers improve supply chain efficiency. Improved supply chain efficiency may help SME organizations to maintain competitiveness in a rapidly globalizing economy. The paper also gives some suggestions on how SMEs can cope with the challenges that they face. The supply chain management practices suggested in this paper provides a framework for realizing true supply chain efficiency and competitiveness. Different organizations will align their objectives, processes and management focus as per the focal areas of their organization depending on their capabilities and market situation. However, in every case organizations need to act fast to capitalize on these opportunities to be competitive with the world market.
\end{abstract}

Keywords: Supply Chain Management, Small and Medium Enterprises (SMEs), Sustainable Competitive Advantage, Strategic Alliances, Factor Analysis

\section{Introduction}

World over, Small and Medium Enterprises (SMEs) sector has acquired a significant and pivotal position in the entire development process. Over the years it has played a critical role in the developing economies by generating new employment opportunities and making significant contributions to the national / global economy. However, the sector suffers from various constraints.

In today's context of fast emerging digital economy and dominance of regional and global supply chain systems, the SMEs in developing countries, besides facing traditional hardships of finance and procedural delays, are critically lagging behind due to obsolete technology and production process, lack of modern delivery and marketing techniques, information asymmetry and lack of knowledge management capacity. An important and comprehensive issue relating to all these factors is the concept and practice of much needed global supply chain, which is yet to find proper place in the SME sector. SME sector can be made globally competitive by enabling it to enter international supply chain.

In the $21^{\text {st }}$ century business environment, products and services can be out-mode within months and corporate market share at risk almost on daily basis, hence the reason 
why supply chain management, as a source of sustainable competitive advantage, is a very hot topic in business today. Supply chain management choices and strategies have an increasing critical influence on strategic business outcomes. Currently, supply chain management practices, in terms of the convergence of information flows, products and service flows, logistics, and payment flows, are transforming the ways that companies produce goods, market them and provide services and hence create increasing value for customers [9]. Hence effective Supply Chain Management may not only be the source of survival and growth but also the origin of strategic relationships for a competitive advantage.

A supply chain is the sequence of organizations, their facilities and functions that are involved in producing and delivering a product or a service. The sequence begins with the basic suppliers of raw materials and extends all the way to the final consumers. Facilities include warehouses, processing centers, distribution centers, retail outlets and offices. Functions and activities include forecasting, inventory management, information management, quality assurance, scheduling, production, distribution, delivery and customer service. There are three kinds of movements in these systems; the physical movement of materials, the flow of cash backward through the chain and information which moves in both directions along the chain [33].

\subsection{The Small Scale Tea Sector in Kenya}

Tea was introduced into Kenya from India in 1903 by a European colonial settler Mr. G. W. Caine who planted the first tea plants in Limuru area. The early settlers and the colonial government restricted tea growing to large scale farmers and multi-nationals to lock out the locals (Africans). When Kenya attained independence in 1963, such laws were changed which allowed Africans to grow tea as small scale farmers. The Special Crops Development Authority (SCDA) which managed the tea industry before independence was converted into Kenya Tea Development Authority (KTDA) in 1963. This divided the tea industry into two sectors namely the small scale sector managed by the KTDA and the large scale sector managed by the Kenya Tea Growers Association (KTGA). The large scale tea sector is owned mainly by large multi-national companies with big plantations under tea with a processing factory within the farm. The KTDA was mandated to develop and run the small scale tea sector under the Tea Act (Cap 343) of the laws of Kenya [20]

A small scale farmer is one who owns a piece of land and has a tea license permitting growing and plucking of green leaf and delivering it to a buying centre run by KTDA. On average tea land holdings are very small, some having less than half an acre. Indeed $70 \%$ of small scale tea farmers own half an acre and less and 90\% own one acre and less. Cultural factors have greatly contributed to land subdivisions. However some farmers with farms more than 50 acres are also classified as small scale farmers. This implies that a small scale farmer, in Kenya, is classified as small not because of the size of the farm but due to lack of a processing factory within the farm and is therefore forced to sell his green leaf to the KTDA Ltd managed tea factories.

The small -scale tea sector is composed of small- scale tea farmers who are the suppliers of the raw materials, the processing factories and the Kenya Tea Development Authority (KTDA), now the Kenya Tea Development Agency Ltd (KTDA Ltd). The small scale tea farmers supply the major primary raw material (green leaf) which is plucked (two leaves and a terminal bud) from the tea plant. The raw material is very perishable and so is transported to a tea factory for processing soon after harvest. This is the reason why the factories are located near the tea farms (raw materials) in the rural areas.

The small scale tea sector plays a very important role to the Kenya economy. The sector contributes significantly to employment as the harvesting of green leaf and tea processing are both labour intensive processes. The tea industry is the largest employer in the private sector with more than 100,000 people working in the estates and about 5 million people earning their livelihood from the sector [13]. The sector also assists in regional and local development by accelerating rural industrialization which uses the locally available raw materials. It also contributes to the GDP, Economic growth and wealthy creation which assist in poverty reduction especially in the rural areas. The tea industry assists the country in getting foreign exchange earnings which assist in foreign exchange transactions.

\subsection{Literature Review}

Supply Chain Management (SCM) is a business practice that aims to improve the way a business sources its raw materials, and delivers its final products to the end users. For any product or service offered by any business, there are usually a number of different business entities involved in the various stages of the supply chain, including manufacturers, wholesalers, distributors and retailers; the last group in a supply chain is consumers. SCM is important for modern businesses because it coordinates and synchronizes activities of partner businesses, giving higher efficiency.

[14] Acknowledge that many contemporary authors writing on the topic of supply chain management refer to this trend as a "new" or "relatively new" concept in management theory. However, [8] holds that the role of supply chain management has changed considerably over the past 30 years, thereby concluding that the concept has been around for a considerable period of time. According to [19], the concept was introduced in 1984.

[35] Claims that Forrester is the true father of the philosophy of supply chain management. Further, as noted in [14], the literature often claims that supply chain management is an "extension of logistics" and also that it is a further development in managing the supply base and therefore a development of the purchasing function. [16], believes that physical distribution (logistics) has been expanded into the broader concept of supply chain management. [30] Have another belief, namely that there is no distinction between supply chain management and 
logistics and the former is an evolutionary extension of logistics.

Although different authors have opposing views, supply chain management is a product of the dramatic changes in business during the 1990s. Supply chain management developed over at least four decades, but the fact remains that it developed from logistics and purchasing. Besides logistics, other functional areas such as marketing finance and operations management made an equally significant contribution [14]. Despite the fact that there is no generally agreed definition, supply chain management (SCM) is generally intended to cover all business processes between vertically linked organizations [20], [4].

In the face of a competitive global market, organizations have downsized, focused on core competencies, and attempted to achieve competitive advantage by more effectively managing all internal and external value-adding activities. Many firms have reduced their supply base so they can more effectively manage relationships with strategic suppliers [34]. The literature indicates that buying firms are developing cooperative, mutually beneficial relationships with suppliers and viewing suppliers as virtual extensions of their firm [6]. Superior supplier capability can lead to exceptional quality or rapid integration of the latest technological breakthroughs into the buying firm's own products through early supplier involvement [28]. Suppliers may also participate earlier in the product design process to render more cost-effective design choices, develop alternative conceptual solutions, select the best components and technologies, and help in design assessment [24], [5].

As organizations move towards increased global competitiveness, supply chains face new issues and challenges. These include increasing demands to reduce costs, increase quality, improve customer service and ensure continuity of supply [11], [26]. The supply chain environment is characterized by globalization, increased customer responsiveness, channel integration and advances in information and communication technologies (ICT). Organizations in supply chains are compelled to restructure and re-engineer relentlessly to increase their effectiveness and satisfy customers. This realization requires firms to look beyond their organizational boundaries and evaluate how the resources and capabilities of suppliers and customers can be utilized to create exceptional value.

Supply Chain Management is an important area of management and business in these days of volatile and dynamic business environment. The business environment is replete with ever changing competitive challenges that call for equally responsive and matching management strategies and hence the urgent need for an effective Supply Chain Management for any firm. Organizations must, therefore, ensure that their Supply Chain Management practices are sufficiently agile, adaptable and aligned to the changing environmental conditions in order to achieve a sustainable competitive advantage [9].

The following paragraphs describe some of the best supply chain management practices which if implemented would lead to sustainable competitive advantage for SMEs in Kenya and other developing countries.

Information technology (IT) is essential to develop and maintain a successful SCM philosophy. Companies implement information systems to monitor inventory levels and schedule production, to provide high levels of customer service, and to enhance their competitive position through partnerships. SCM is concerned with product flows and information flows. Information flows in both directions through the supply chain. The current emphasis on supply chain re-engineering essentially means, changing an organization from the flow of things to the flow of information [18].

In recent years numerous studies have emphasized the importance of information sharing within the supply chain [2], [21], [22], [32]. Indeed information sharing is a prerequisite for successful operation of the SC [23]. While there is no doubt about the importance of information in the supply chain and about the fact that information technology (especially various Internet applications) can greatly reduce the costs, strategic planning of this process and utilization of information is crucial. Information should be readily available to all companies in the supply chain and the business processes should be structured in a way to make full use of this information.

In the past, holding large amounts of inventory was a typical business practice. This was due to the uncertainty involved in dealing with many suppliers. The current business trend is to reduce or eliminate inventory wherever possible, but it is important to understand the balance between customer service and inventory. [1] States that increased customer service is a reason to hold inventory. "Inventories provide a level of product or service availability, which, when located in the proximity of the customer, can meet a high customer service requirement" [1]. Inventory close to the customer can also reduce cost of lost sales and result in repeat customers. Holding any amount of inventory may result in some form of expense particularly carrying costs. On the other hand, the reasons for holding inventory can indirectly reduce operating costs realized in other company activities [1]. These cost reductions can be pricequantity discounts, lower transportation rates, or holding safety stock to insure against stock outs [7].

Collaboration can best be described as an interorganizational relationship type in which the participating parties agree to invest resources, mutually achieve goals, share information, [29], [12], [32], [3], resources, rewards [27] and responsibilities as well as jointly make decisions and solve problems [31]. Collaboration is based on mutual trust, openness, shared risk and shared rewards that yield a competitive advantage, resulting in better performance than it would be without the collaboration [13]. It implies cooperation and some form of alliance between two or more organizations. These are formed for sharing the costs of large investments, pooling and spreading of risk, and access to complementary resources. Similarly, firms establish close, long-term working relationships with suppliers and 
customers, who depend on one another for much of their business, developing interactive relationships with partners who share information freely, work together when trying to solve common problems when designing new products, who jointly plan for the future, and who make their success interdependent [31]. More and more companies are collaborating in the supply chain because of market diversity, competitive pricing and shorter product life cycles.

[17] Regard supply chain integration as a strategic tool aimed at reducing costs and thus increasing customer and shareholder value. Hence effective supply chain planning, built on shared information and trust among partners is a vital part of successful supply chain functioning. [25] Define integration as "The process of incorporating or bringing together different groups, functions, or organizations, either formally or informally, physically or by information technology, to work jointly and often concurrently on a common business-related assignment or purpose".

In summary best Supply Chain Management Practices provides strategies and methods of integrating separate organizations in the supply chain and their functions into a cohesive operating system. The benefits of the best Supply Chain Management Practices include lower inventories, lower costs, higher productivity, greater agility, shorter lead times, higher profits and greater customer loyalty. These benefits may lead to a competitive advantage that subsequently leads to increase shareholder value.

\subsection{The Research Problem}

The small scale tea sector makes a significant contribution to the Kenyan economy in general. The businesses that operate in the sector will only survive and grow if they are able to compete internationally as their final product (manufactured tea) is exported. To compete internationally, the focus is no longer on the management, survival, growth and competitiveness of individual organizations, but on supply chains. Suppliers can be a crucial source of competitive advantage for an organization in their own value package they offer to the customers in the market.

The small scale tea sector has had tremendous growth from 1963 when it was started by the government. The sector started with only one factory serving 19,000 growers and has now about sixty tea factories serving over 560,000 farmers who produce about 750 Million kilograms of green leaf annually. The sector produces over sixty percent of Kenyan tea.

On several occasions small scale tea farmers have been reported complaining of several problems associated with supply chain management practices in the sector. The farmers have always complained of low and delayed payments, both of which are supply chain problems. The supply chains in the sector are said to be too long and this adds costs to the business which results in reduced payments to the farmers who are at the bottom of the supply chain. The low payments to farmers are beginning to negatively affect production. This is evident in some areas where tea farms are being neglected and in some extreme cases tea bushes uprooted [15]. In other cases the tea farmers sell their green leaf to unlicensed middlemen to get quick cash. Such practices by tea farmers may cause supply chain management challenges to the sector.

\section{Research Methodology}

This study was done by conducting a survey as the research design. Quantitative surveys provide information and explanations that are adequate enough for drawing reasonable conclusions. The survey design was used to provide an opinion of the supply chain management practices and challenges for the small scale tea sector in Kenya. The required data was collected from the KTDA Ltd, which is the management agent of the sector. The KTDA Ltd has its management staff at its head office in Nairobi, at the regional offices and factory premises which are spread across the country. As the KTDA Ltd manages about sixty tea processing factories, the total population involved about six hundred, all of whom are management staff.

Stratified random sampling technique was used to obtain the required data. There are different categories of staff in the field (factories) that have different qualities which make stratified random sampling the most suitable method of data collection. They include tea extension staff, logistics staff and manufacturing staff in factories. There are also other categories of staff at the head office who are working in stages of the supply chain. These categories of staff include those in charge of tea transportation to warehouses, warehousing, marketing, ICT and others. All these categories of staff provided the required data on the supply chain management practices and challenges for the small scale tea sector in Kenya.

Questionnaires were sent to one sixth (1/6) of the total population of members of staff. This gave a sample of one hundred questionnaires and this sample size was representative enough to provide the required data. The sample size included a total of one hundred members of staff from each of the four categories (strata) and involved extension staff, logistics staff, operations staff and the general staff at the head office. A sample was selected using a simple convenient stratified random sampling technique. Out of a total number of 100 respondents targeted for this study, only 48 completed and returned the survey instrument.

The data was collected using structured questionnaires and also a face to face interview was conducted on selected respondents on the other challenges that face the sector.

The data was tabulated for analysis which included mainly descriptive statistics and factor analysis. Tables were used in summarizing the analyzed data and hence assisted in answering the research questions. The descriptive analysis was used to give an opinion or picture of the Supply Chain Management practices in the sector. The same analysis also revealed the general patterns of the supply chain management practices. Factor analysis was used to analyze the supply chain management challenges for the small scale tea sector in Kenya. Factor analysis has the advantage of reducing many variables to a small number of factors that easily explain a 
phenomenon. Hence factor analysis was used to reduce the variables which were initially 22 to only 8 factors that explain the challenges which face the sector.

\section{Results of the Study}

The survey analyzed and interpreted responses to questions asked respondents on issues relating to Supply Chain Management practices and challenges for the small scale tea sector in Kenya. The responses were obtained from the different categories of staff who work along the supply chain in the sector.

\subsection{Supply Chain Management Practices}

The results indicate that KTDA Ltd has contracts with suppliers and also the small scale tea farmers and it is important to have such supply contracts with players in the supply chains. This is in agreement with the good supply chain management practices. However it was noted that KTDA has not established long lasting relationships with its suppliers as was evidenced by the frequent seeking of suppliers through tenders. This explains partly why the relationship with suppliers is not very good. It was noted that some of the suppliers do not know their roles especially on issues concerning quantity and quality specifications and time of delivery. This was noted especially on middle level suppliers located in the small towns near the factory companies. This is very strange especially in a very competitive environment.

The results indicate KTDA Ltd beliefs that it is not important to aid suppliers in terms of information, location and specifications of contract requirements. In to-days competitive environment, suppliers may be a source of competitive advantage in business and therefore need to be aided. It is surprising that suppliers are not aided for an organization like KTDA Ltd which is competes in the international markets.

It was noted that KTDA Ltd belief that integrating supply chains is important. Supply chain integration reduces costs and hence increases shareholder value which ultimately leads to sustainable competitive advantage. This is consistent with existing supply chain management practices.

It was found that supply chain is a key to a sustainable competitive advantage. Implementing good SCM practices results in efficiency, cost reduction, and better-quality services which finally gives a business a sustainable competitive advantage. This is in agreement with best supply chain management practices. Effective supply chains improve performance. Effective supply chains may mean best supply chain management practices. Such practices may lead to efficiency and this may also lead to reduced inventories, reduced lead times, reduced costs and better service to customers. Such benefits of best supply chain management practices not only improve performance but also lead to competitive advantage in the long run.

The relationships among the supply chain members are partly stable and that supply chain members partly share information. The relationship among members may not be very stable because of stiff completion within the supply chains. Such competition is expected especially in this industry where we have very many players competing for the same scarce resources. Under such circumstances the players may not share information among themselves more especially among the small businesses that may not only afford but also see the benefits of information technology. Supply chain members partly share information. This is strange as information sharing is important as it leads to better understanding and in making of timely decisions.

It was found that the supply chains in the sector are too long and each stage involves some costs. Such long stages of supply chains add some costs of operations. The stages are too long as compared with the large scale estates that have short and efficient supply chains. Reducing such long stages may minimize costs and also improve performance.

\subsection{Supply Chain Management Challenges}

The data collected was tabulated as raw data and analyzed using (SPSS) package for factor reduction technique to determine the important factors that cause challenges to the sector.

Factor analysis was used to identify a smaller set of factors to represent the relationships among the variables parsimoniously (i.e. to explain the observed correlation with fewer factors). In this research, principal components analysis with Eigen values greater than one was used to extract factors, and varimax rotation was used to facilitate interpretation of the factor matrix. The factors were assumed to represent the variables and were done sequentially in several stages that include;

\section{(i) Correlation matrix}

A matrix of correlation coefficients was generated for the 22 variables. This was done to show the inter-relationships between the different variables. Since the purpose of factor analysis is to link variables together into factors, those variables must therefore be related to one another. Variables which measure the same dimension or dimensions are expected to be correlated because they measure the same things. From the matrix it was found that two variables, namely green leaf variability and lack of transport were not or were poorly correlated with the other variables.

Variables that were not highly correlated may not measure the same factor. This implies that these two variables may not jointly measure or be associated with one same factor. Hence the two variables may not be grouped together with the other variables in factor extraction. The same variables had very low factor loadings in the rotated component matrix, meaning that the variables were poorly correlated with the factors extracted. As the variables were not correlated with any of the variables, the two variables (green leaf variability and lack of transport) were removed from the analysis and therefore do not appear anywhere in factor reduction process.

(ii) Factor extraction

The next stage is the extraction of factors from the correction matrix. The most common method of doing this is 
by using the principal factors technique which is sometimes referred to as principal components extraction technique (PC). The factors were selected one by one using the Eigen values greater than one as selected. The Eigen value of a factor is the total variance accounted for by the factor. The first factor extracted has the largest Eigen value, the second the next largest Eigen value and so on. The process of extraction continues until the factors extracted account for a negligible proportion of the total variance. The Eigen values greater than one explain a very big percentage of the total variances that explain the challenges that face the small scale tea sector in Kenya. When the Eigen values of successive factors are plotted against the ordinal numbers of the factors, they form a curve called a Scree plot, as shown in Figure 1 below.

\section{Scree Plot}

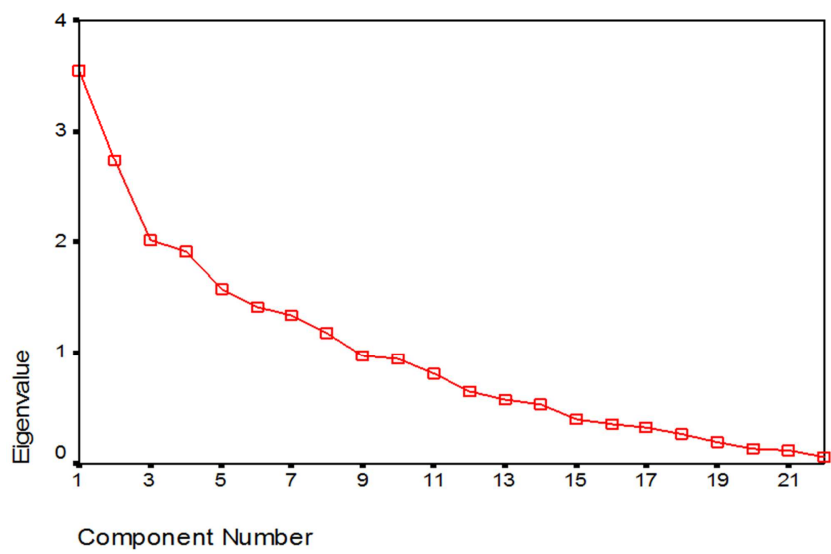

Figure 1. A plot of the Eigen values and components to indicate the important factors.

The factors with Eigen value greater or equal to one was used to determine the number of factors to retain. This was further illustrated by using the scree plot (above) which indicates that the screes started to tee-off after factor 8 implying that only 8 factors explain the challenges that face the small scale tea sector in Kenya. The Eigen values for each component (factors) together with their associated percentages of the variances explained show that only eight factors (items with Eigen values greater than one) can be extracted to explain the challenges. These eight factors explain up to $71.2 \%$ of the challenges and the remaining percentage of 28.8 can be explained by other factors.

\section{(iii) Factor rotation}

The last process is factor rotation where factors are rotated to maximize the relationships between the variables and minimize their association with others. The most common method of doing this is by using the varimax technique. This method maintains independence among the mathematical factors. The factors are rotated around the fixed original until the loadings meet certain criteria. The set of loadings that satisfies the criteria are called the rotated factor matrix. The purpose of rotation is to arrive at a factor matrix with a pattern of loadings that is easier to interpret than the original factor matrix, hence a minimum number of factors. The factors extracted are summarized and explained in table 1 below;
Factor Reduction for the Supply Chain Management challenges for the Small Scale Tea sector in Kenya

Table 1. Shows the factors extracted.

\begin{tabular}{|c|c|c|c|}
\hline Factor & Item Description & $\begin{array}{l}\text { Factor } \\
\text { Loadings }\end{array}$ & $\begin{array}{l}\text { Interpretation of } \\
\text { the factors }\end{array}$ \\
\hline \multirow{3}{*}{1} & (i) Motor vehicle maintenance & 0.782 & \multirow{3}{*}{$\begin{array}{l}\text { Unstable working } \\
\text { environment }\end{array}$} \\
\hline & (ii) Poor working environment & 0.729 & \\
\hline & (iii) Unstable world tea prices & 0.770 & \\
\hline \multirow{3}{*}{2} & (i) Fleet management & 0.778 & \multirow{3}{*}{$\begin{array}{l}\text { Lack of good } \\
\text { management } \\
\text { policies }\end{array}$} \\
\hline & $\begin{array}{l}\text { (ii) Lack of Information flows in } \\
\text { the supply chain system }\end{array}$ & 0.702 & \\
\hline & $\begin{array}{l}\text { (iii) Interferences from directors/ } \\
\text { famers }\end{array}$ & 0.514 & \\
\hline \multirow{3}{*}{3} & $\begin{array}{l}\text { (i) Lack of good information } \\
\text { system }\end{array}$ & -0.628 & \multirow{3}{*}{$\begin{array}{l}\text { Unpredictable } \\
\text { interferences } \\
\text { from the } \\
\text { environment }\end{array}$} \\
\hline & $\begin{array}{l}\text { (ii) Unpredictable weather } \\
\text { conditions }\end{array}$ & 0.796 & \\
\hline & (iii) Political interferences & 0.631 & \\
\hline \multirow{3}{*}{4} & $\begin{array}{l}\text { (i) Competition from large } \\
\text { producers }\end{array}$ & 0.621 & \multirow{3}{*}{$\begin{array}{l}\text { Stiff competition } \\
\text { within the supply } \\
\text { chains }\end{array}$} \\
\hline & $\begin{array}{l}\text { (ii) Lack of cooperation within } \\
\text { supply chain }\end{array}$ & 0.673 & \\
\hline & (iii) Lack of farm inputs & -0.708 & \\
\hline \multirow{2}{*}{5} & (i) Motor vehicle routing & 0.878 & \multirow{2}{*}{ Quality problems } \\
\hline & (ii) Poor quality of raw materials & -0.554 & \\
\hline \multirow[b]{2}{*}{6} & (i) Rising operating costs & 0.537 & \multirow{2}{*}{$\begin{array}{l}\text { Increasing } \\
\text { operating costs }\end{array}$} \\
\hline & $\begin{array}{l}\text { (ii) Lack of trust in the supply } \\
\text { chains }\end{array}$ & 0.749 & \\
\hline \multirow[b]{2}{*}{7} & (i) Licensing of tea farmers & 0.620 & \multirow{2}{*}{$\begin{array}{l}\text { Poor } \\
\text { management }\end{array}$} \\
\hline & $\begin{array}{l}\text { (ii) Poor management of } \\
\text { inventories }\end{array}$ & 0.788 & \\
\hline \multirow{2}{*}{8} & $\begin{array}{l}\text { (i) Lack of interest in the supply } \\
\text { chains }\end{array}$ & 0.843 & \multirow{2}{*}{$\begin{array}{l}\text { Lack of supply } \\
\text { chain linkages }\end{array}$} \\
\hline & $\begin{array}{l}\text { (ii) Lack of supply chain } \\
\text { cooperation }\end{array}$ & 0.560 & \\
\hline
\end{tabular}

In summary, only eight important factors can be used to explain the challenges that face the small scale tea sector in Kenya. The factors are Unstable working environment, Lack of good management policies, Unpredictable interferences from the environment, Stiff competition within the supply chains, Quality problems, Increasing operating costs, Poor management and Lack of supply chain linkages.

\section{Conclusions}

This study concluded that although the small scale tea sector appreciates good supply chain management practices, the same has not been fully incorporated in the operations of the sector. It was found that though the KTDA Ltd believes in strong and stable relationships with its suppliers, the reality is completely different. The company has not taken any steps to draw its suppliers into long term stable relationships as it does not offer long term supply contracts. It was found that in many instances supply contracts are drawn annually including specialized and international contracts. This is evidenced by annual tenders and contracts that are always done at specific dates of their annual financial calendars. This is at variance with good supply chain management practices.

The study noted that KTDA Ltd has not established strong and long term relationships with its suppliers. There were 
also no good relationships among the supply chain members operating within the sector. The members of the supply chain can improve their relationships by creating and maintaining of partnerships among themselves, effective communication and continuous communication, adoption of a culture of competitiveness, quality control and review. It is therefore necessary that members of the supply chain to work in partnership with the KTDA Ltd to achieve full benefits of good supply chain management practices.

Several adverse forces presently threaten the growth and the long term survival of the tea industry which include the small scale sector. The most worrying problem is the danger caused by the rising costs of production more especially the labour and oil prices that are continuously rising. For labour, the main problem arises from the pattern of wage awards which have risen more than 10 times since 1990. This has made tea farming to be unprofitable business for some small scale farmers. The danger signals are evident from the small producers who have started diversifying their farming away from tea farming. Some small scale farmers have started uprooting their tea plants while others have either abandoned tea farming or selling their produce to middlemen to get quick cash for survival.

The other threat comes from the weak trend in export price of tea in the world markets. This is caused by a consistent surplus of tea supply into the world markets which depresses auction prices. The dollar price has been constant for a long time.

Although the districts that grow tea receive adequate amounts of rainfall, drought periods affect production leading to wide fluctuations in output. Output fluctuations contribute to the decline in earnings. Poor infrastructure, unreliable and costly electricity, high costs of fuel and packaging materials increase production costs. All these forces combined cause very serious challenges to the long term survival of the small scale tea sector in Kenya.

Africa belongs to the developing world where the major activities are primary activities which include mainly agricultural farming, mining, forestry, fishing and others. Due to poverty most of such activities are done not for commercial purposes. Hence such activities are done on small and medium scale. The SME sector accounts for over 95\% of businesses in Africa. This sector in Africa faces many challenges that include adverse and unpredictable climatic conditions, unstable world markets, rising operating costs, poor and incompetent management, cultural and legal and political interferences. All these factors make the sector to be operating just marginally and therefore not competitive in the global environment. Unless these challenges are addressed, the long term survival of the SMEs is uncertain.

\section{Limitations of the Study and Suggestions for Further Research}

This research was a case study of the small scale tea sector in Kenya. Data was collected from a small sample and therefore may not reflect fully the true picture of the SME sector in Kenya and in Africa in general. We therefore suggest further research to be done in other countries to cover crops like coffee, cocoa, rubber, rice and also in other business areas.

\section{References}

[1] Ballou,. H. (1992), Business Logistics Management, PrenticeHall, Englewood Cliffs, NJ.

[2] Barrat, M. 2004). Understanding the Meaning of Collaboration in the Supply Chain, Supply Chain Management: An International Journal, Vol 9 No. pp 30-42.

[3] Barratt, M. \& Oliveira, A. (2001), "Exploring the experiences of collaborative planning Initiatives", International Journal of Physical Distribution \& Logistics Management, Vol. 31 No. 4, pp. 266-89.

[4] Bask, A. H. \& Juga, J. (2001), "Semi-integrated supply chains: towards the new era of supply Chain management", International Journal of Logistics: Research \& Applications, Vol. 3 No. 1, pp. 5-23.

[5] Burt, D. N. \& W. R. Soukup. (1985), "Purchasing Role in New Product Development," Harvard Business Review, pp. 90-97.

[6] Copacino, W. C. (1996), "Seven Supply-Chain Principles," Traffic Management, (35:1), pp. 60

[7] Coyle, J. J., Bardi, E. J. \& Langley, C. J. Jr (1996), the Management of Business Logistics, $6^{\text {th }}$ ed., West, New York, NY.

[8] Gattorna JL (1998). 'Strategic Supply Chain Alignment: Best practice in supply chain management'. Gower publishing limited: England.

[9] Gekonge C. O (2006), Supply chain management, KASNEB news-line issue no. 2 of 2006.

[10] Gesimba. R. M (2005). The Tea Industry in Kenya; The Challenges and Positive developments.

[11] Goebel, D. L., Marshall, G. W. \& Locander, W. B. (2003), "Enhancing purchasing's strategic reputation: evidence and recommendations for future research", Journal of Supply Chain Management, Vol. 39 No. 2, pp. 4-13.

[12] Gray, B. \& Hay, T. M. (1986), "Political limits to interorganizational consensus and change", The Journal of Applied Behavioral Science, Vol. 22 No. 2, pp. 95-112.

[13] Gunasekaran, Angappan, Patel, Christopher and Tirtiroglu, Emerald. "Performance Measures and Metrics in a Supply Chain Environment", International Journal of Operations \& Production Management, Vol. 21(1-2), 2001, 71-87.

[14] Hugo, WMJ, Badenhorst-Weiss, J A., \& Van Biljon, EHB., (2004). Supply Chain Management - Logistics in Perspective. Van Schaik, Pretoria.

[15] Kirambi A, Ombuki C, Mweseli A, Lumbasio E (2008) A Christian Partnership Development Agency (CPDA) Report on small scale tea sector in Kenya.

[16] Kotler, P. 2000. "Marketing Management Planning: Analysis and Control, a strategic approach", Mc grawhill, USA. 
[17] Kwon, I. G. \& Suh, T. (2005), "Trust, commitment and relationships in supply chain Management: a path analysis", Supply Chain Management: An International Journal, Vol. 10 No. 1, pp. 26-33.

[18] La Londe, B. J. \& Powers, R. F. (1993), "Disintegration and re-integration: logistics of the Twenty-first century", The International Journal of Logistics Management, Vol. 4 No. 2, pp. 1-12.

[19] Lamming R (1996). 'Squaring lean supply with supply chain management'. Int. J. Oper. Prod. Manage. 16(2).

[20] Lambert, D. M. \& Cooper, M. C. \& Pagh, J. D. (1998) "Supply chain management implementation issues and research opportunities "The international journal of logistics management, Vol 9. No. 2 Pp 1-19

[21] Lambert, D. M. \& Cooper, M. C. (2000), "Issues in supply chain management", Industrial Marketing Management, Vol. 29 No. 1, pp. 65-83.

[22] Lau, HCW \& Lee, WB. (2000). on a responsive supply chain system. International journal of physical distribution \& logistics management. Volume 30. Issue 7/8. 598.

[23] Mason-Jones, R. \& Towill, D. R. (1997). Information enrichment: Designing the supply chain for competitive advantage.

[24] Monczka, R. M., R. J. Trent, \& T. J. Callahan (1994). "Supply Base Strategies to Maximize Supplier Performance," International Journal of Physical Distribution and Logistics, (24:1), pp. 42-54.

[25] Monczka, R., Trent, R. \& Hand field, R. (2005), Purchasing and Supply Chain Management, $3^{\text {rd }}$ ed., Thomson SouthWestern, Mason, $\mathrm{OH}$.

[26] Pearson, J. N., Ellram, L. M. \& Carter, C. (1996), "Status and recognition of the purchasing function in the electronics industry", International Journal of Purchasing and Materials Management, Vol. 32 No. 2, pp. 30-6.

[27] Phillips, N., Lawrence, T. \& Hardy, C. (2000), "Interorganizational collaboration and the dynamics of institutional fields", Journal of Management Studies, Vol. 37 No. 1, pp. 2344.

[28] Ragatz, G., R. Handfield, \& T. Scannell (1997). "Success Factors for Integrating Suppliers into New Product Development," Journal of Product Innovation Management, (14), pp.190-202.

[29] Ring, P. \& Van de Ven, A. (1994), "Developmental processes of cooperative inter-organizational relationships", Academy of Management Review, Vol. 19 No. 1, pp. 90-118.

[30] Simchi Levi, D., Kaminsky, P. \& Simchi-Levi, E. (2003), Designing and Managing the Supply Chain: Concepts, Strategies, and Case Studies, McGraw-Hill, New York, NY.

[31] Spekman, R. E., Kamau F. F, J. W. Jr \& Myhr, N. (1998), “An empirical investigation into supply chain management: a perspective on partnerships", International Journal of Physical Distribution \& Logistics Management, Vol. 3 No. 2, pp. 5367.

[32] Stank, T. P., Crum, M. R., \& Arango, M. (1999), "Benefits of inter-firm coordination in food industry supply chains", Journal of Business Logistics, Vol. 20 No.2, pp.21-41.

[33] Stevenson, WJ. 2007. Operations management. $9^{\text {th }}$ Edition. Boston: McGraw-Hill.

[34] Tully, S (1995). "Purchasing's New Muscle," Fortune, (20), p. 76.

[35] Warner M (2002) (Ed). 'International Encyclopedia of Business management', 2nd ed. Singapore: Thomson learning. 